\title{
Potensi Antibakteri Ekstrak Daun Pelawan Merah (Tristaniopsis Merguensis Griff.)
}

\author{
Auronita Puspa Pertiwi \\ Jurusan Farmasi, Poltekkes Kemenkes Pangkalpinang, Indonesia \\ Email korespondensi : auronitapuspa@gmail.com
}

\begin{abstract}
Abstrak
Daun Pelawan Merah dikenal masyarakat sebagai tumbuhan yang dimanfaatkan untuk obat tradisional diare. Diduga kandungan fitokimianya berpotensi sebagai bahan alami antibiotik. Penelitian ini bertujuan untuk melihat potensi daun Pelawan Merah sebagai antibakteri.

Ekstrak dibuat dengan 3 pelarut, yaitu etanol, etil asetat dan n-heksana. Pengujian dilakukan dengan metode difusi cakram terhadap 3 bakteri yaitu Staphylococcus aureus, Escherichia coli, dan Bacillus subtilis. Aktivitas antibakteri diketahui melalui pengukuran diameter zona hambat yang terbentuk pada media bakteri setelah diberi perlakuan dan diinkubasi selama 24 jam.

Hasil penelitian menunjukkan ekstrak n-Heksana memiliki daya hambat lemah terhadap S.aureus dan B.subtilis. Ekstrak etanol menunjukkan daya hambat lemah hingga sedang terhadap S.aureus, sedangkan pada E.coli dan B.subtilis tampak adanya daya hambat sedang. Ekstrak etil asetat menunjukkan daya hambat sedang terhadap E.coli, dan daya hambat lemah hingga kuat terhadap B.subtilis dan S.aureus.
\end{abstract}

Kata kunci: antibakteri, Daun Pelawan Merah

\section{Antibacterial Activity Of Pelawan Merah (Tristaniopsis Merguensis Griff.) Leaves Extract}

\begin{abstract}
Pelawan Merah leaf has been used by local people as traditional treatment for diarrhea. It's phytochemical components are allegedly as potencial natural antibiotic. This study aimed to determine Pelawan Merah leaves antibacterial potency.

This research was carried out through antibacterial test of Pelawan Merah leaves extract against Staphylococcus aureus, Escherichia coli, dan Bacillus subtilis. Leaves extracted by maseration method in ethanol, ethil acetate and n-hexane solvent. Antibacterial activity was determined based on measurement of inhibition zone after $24 \mathrm{~h}$ incubation.

Result showed that n-hexane extract has low inhibition to S.aureus dan B.subtilis. Ethanol extract showed low to moderate inhibition against S.aureus, and moderate inhibition to E.coli and B.subtilis. Ethil acetate showed moderate inhibition to E.coli and moderate to strong inhibition to B.subtilis and S.aureus.
\end{abstract}

Keywords: antibacterial, Pelawan Merah leaves

\section{PENDAHULUAN}

Riset menunjukkan bahwa komponen aktif dalam tumbuhan obat memiliki efek antimikroba yang berbeda mekanisme kerjanya dari antibiotik yang sudah ada selama ini. Hal ini menunjukkan potensi tumbuhan obat dalam mengatasi masalah resistensi antibiotik (Ganapathy dan Karpagam, 2016). Oleh sebab itu, saat ini pengembangan untuk penemuan antimikroba dari tanaman dianggap penting dan memberikan harapan baru untuk penelitian selanjutnya.

Salah satu tumbuhan yang dimanfaatkan sebagai obat tradisional adalah Pelawan Merah (Tristaniopsis merguensis Griff.). Secara empiris, tumbuhan ini digunakan untuk mengobati berbagai penyakit diantaranya adalah sebagai obat diare (Masyarakat Desa Penagan, 2018). Asmaliyah (2016) membuktikan bahwa daun Pelawan 
Merah mengandung flavonoid, tanin, saponin, steroid dan triterpenoid.

Beberapa jenis tumbuhan dari genus Tristaniopsis telah diketahui berkhasiat sebagai obat. Palajit et al. (2008) melaporkan potensi $T$. burmanica sebagai obat antibakteri, dan $T$. laurina dilaporkan berpotensi sebagai obat antimikroba dan antioksidan (US Patent Application 2008; Florence et al. 2012). Panagan dan Syarif (2009) melaporkan bahwa asap cair hasil pirolisis kayu $T$. abavata dapat menghambat pertumbuhan bakteri Escherichia coli. Menurut Sartika (2013) ekstrak etanol daun Pelawan Putih (Tristaniopsis whiteana) mengandung senyawa flavonoid, alkaloid, tanin, fenol dan terpenoid. Senyawa - senyawa tersebut diketahui memiliki daya antibakteri. Penelitian Vivi (2017) menunjukkan adanya senyawa terpenoid dan alkaloid pada kulit batang $T$. merguensis yang memiliki aktivitas penghambatan pertumbuhan Bacillus subtilis.

Meskipun telah diketahui memiliki kandungan senyawa fitokimia yang berpotensi sebagai antibakteri, namun aktivitas ekstrak daun T. merguensis ini belum dapat dipastikan. Untuk itu masih perlu dilakukan uji untuk mengetahui aktivitas antibakterinya.

\section{METODE}

Penelitian ini merupakan penelitian eksperimental dengan Posttest Only Control Group Design. Proses uji meliputi pembuatan ekstrak dan larutan uji, pemeriksaan kandungan fitokimia serta uji aktivitas antibakteri.

\section{Pembuatan Ekstrak}

Ekstraksi dilakukan dengan metode maserasi selama 5 hari. Selanjutnya hasil maserasi di saring dan dipekatkan dengan evaporator. Larutan uji dibuat dengan konsentrasi masing masing ekstrak (b/v) 20\%, 40\%, 60\%, 80\%, dan $100 \%$.

\section{Pemeriksaan Kandungan Fitokimia}

Uji yang dilakukan meliputi identifikasi flavonoid, alkaloid, tanin, fenol, saponin, dan terpenoid. Identifikasi flavonoid dilakukan dengan mereaksikan 0,5 gram ekstrak dengan

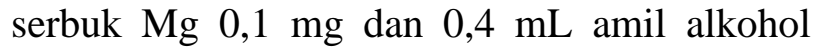
(campuran asam klorida $37 \%$ dan etanol 95\% dengan volume yang sama) dan $4 \mathrm{~mL}$ alcohol, kemudian dikocok. Terbentuknya warna merah, kuning atau jingga pada lapisan amil alkohol menunjukkan adanya flavonoid. Identifikasi tanin dilakukan dengan mereaksikan 0,5 gram ekstrak dengan larutan $\mathrm{FeCl}_{3} 10 \%$. Adanya tanin ditunjukkan dengan terbentuknya warna biru tua atau hitam kehijauan. Identifikasi fenol dilakukan dengan menambahkan 2 tetes larutan $\mathrm{FeCl}_{3} \quad 5 \%$ dalam 0,5 gram ekstrak. Terbentuknya warna hijau atau hijau biru menunjukkan adanya senyawa fenol. Identifikasi saponin dilakukan dengan mereaksikan 0,5 gram ekstrak dengan $10 \mathrm{ml}$ aquades kemudian dikocok vertikal 30 detik. Terbentuknya busa yang stabil menunjukkan kandungan saponin. Identifikasi terpenoid dilakukan dengan mereaksikan 0,5 gram ekstrak dengan 0,5 ml kloroform, 2 tetes asam asetat glasial, dan 2 tetes asam sulfat pekat. Hasil positif ditunjukkan perubahan warna menjadi merah atau keunguan.

\section{Uji Aktivitas Antibakteri}

Metode yang digunakan adalah metode difusi menggunakan cakram kertas steril. Suspensi bakteri diambil dengan cotton swab kemudian dioleskan merata pada permukaan media MHA. Kertas cakram yang telah dicelupkan dalam rutan uji diletakkan di permukaan media pada cawan petri sambil sedikit ditekan, lalu cawan ditutup dan dibungkus dengan plastik seal, kemudian diinkubasi pada suhu $37^{\circ} \mathrm{C}$ selama 24 jam.

\section{HASIL}

Berdasarkan pemeriksaan kandungan fitokimia, teridentifikasi senyawa dalam masing - masing ekstrak sebagai berikut

Tabel 1. Fitokimia Daun Pelawan

\begin{tabular}{|c|c|c|c|c|c|}
\hline \multirow{2}{*}{ Pelarut } & \multicolumn{5}{|c|}{ Kandungan Fitokimia } \\
\cline { 2 - 6 } & Flavonoid & Tanin & Saponin & Terpenoid & Fenol \\
\hline Etanol & + & + & + & steroid & + \\
\hline Etil Asetat & - & + & - & steroid & - \\
\hline n-Heksana & + & - & - & triterpenoid & - \\
\hline
\end{tabular}

Data diperoleh dengan cara melakukan pengukuran diameter zona hambat ekstrak daun Pelawan setelah inkubasi selama 24 jam. 


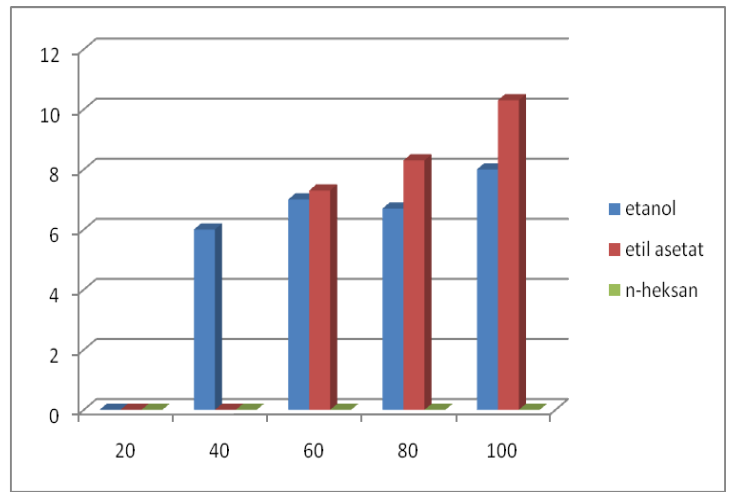

Gambar 1. Hasil Pengukuran Diameter Zona Hambat terhadap E. coli

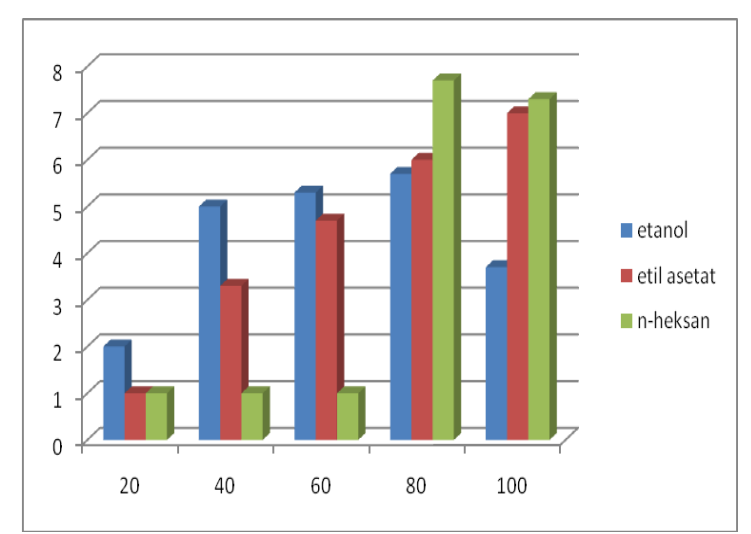

Gambar 2. Hasil Pengukuran Diameter Zona Hambat terhadap $S$. aureus

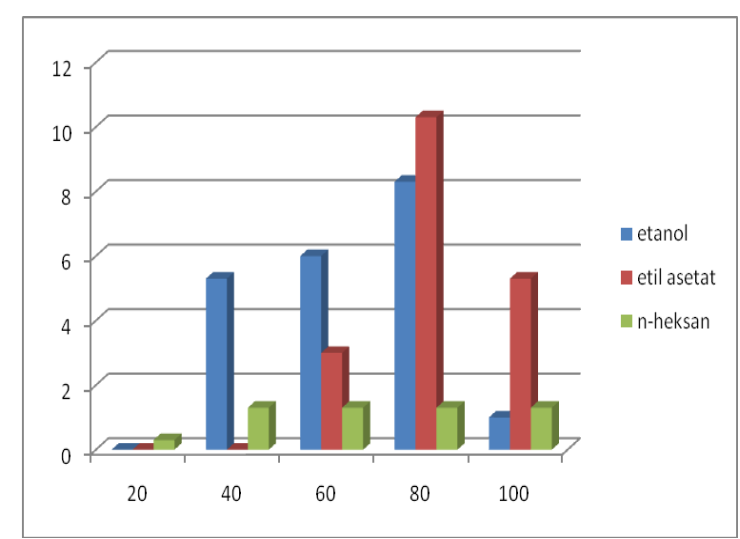

Gambar 3. Hasil Pengukuran Diameter Zona Hambat terhadap B. subtilis

Berdasarkan hasil yang diperoleh, ekstrak n-Heksana tidak mampu menghambat pertumbuhan E.coli. Penghambatan pertumbuhan oleh ekstrak etanol dan ekstrak etil asetat menunjukkan daya hambat lemah hingga sedang. Semua ekstrak menunjukkan aktivitas penghambatan pertumbuhan pada S.aureus dan B.subtilis, pada kategori sedang hingga lemah.

\section{PEMBAHASAN}

Berdasarkan penelitian yang telah dilakukan diketahui bahwa ekstrak daun Pelawan Merah memiliki aktivitas penghambatan pertumbuhan terhadap bakteri yang diujikan baik bakteri gram positif (S.aureus dan B.subtilis) maupun bakteri gram negatif (E.coli). Aktivitas penghambatan pada setiap bakteri yang diujikan berbeda - beda, diduga dipengaruhi kandungan fitokimia serta karakteristik masing - masing bakteri, terutama permeabilitas membran terhadap senyawa aktif dari ekstrak yang diujikan.

Menurut Davis dan Stout (1971), ketentuan aktivitas antibakteri adalah sebagai berikut; daerah hambatan $20 \mathrm{~mm}$ atau lebih berarti sangat kuat, daerah hambatan $10-20$ $\mathrm{mm}$ berarti kuat, $5-10 \mathrm{~mm}$ berarti sedang, dan daerah hambatan $<5 \mathrm{~mm}$ berarti lemah. Rata rata diameter zona hambat yang dihasilkan menunjukkan daya hambat lemah sampai sedang.

Pada E. coli, tidak ada aktivitas penghambatan oleh ekstrak n-Heksana. Berdasarkan uji fitokimia diketahui ekstrak nHeksana daun Pelawan merah mengandung senyawa Flavonoid. Mekanisme kerja flavonoid adalah membentuk senyawa kompleks dengan protein ekstraseluler yang menyebabkan lapisan dinding sel tidak terbentuk secara utuh. Hal tersebut dapat menyebabkan perubahan permeabilitas membran sel yang menghambat kerja enzim intraseluler dan air masuk ke dalam sel secara tidak terkontrol dan diikuti dengan keluarnya senyawa intraseluler (Robinson, 1995 dalam Ainurrohmah, 2013). Karakteristik E.coli memiliki lapisan membran sel yang terdiri dari protein, fosfolipida, dan lipopolisakarida sehingga bersama-sama dengan lapisan peptidoglikan, membentuk mantel pelindung yang kuat untuk sel (Pelczar, 1988). Kompleksitas dinding sel E.coli ini diduga mengakibatkan tidak terjadinya penghambatan pertumbuhan oleh ekstrak n-Heksana daun Pelawan Merah.

Ekstrak etanol dan ekstrak etil asetat menunjukkan adanya aktivitas penghambatan pertumbuhan E.coli pada sebagian konsentrasi uji. Konsentrasi rendah tidak menunjukkan adanya aktivitas penghambatan pertumbuhan. Hal ini dapat disebabkan konsentrasi senyawa aktif di dalam ekstrak juga rendah dan tidak 
cukup untuk mampu menghambat pertumbuhan E.coli. Konsentrasi 60\%-100\% pada ekstrak etanol maupun ekstrak etil asetat sama - sama menunjukkan daya hambat sedang. Diduga senyawa aktif yang berperan adalah Tanin, yang terkandung pada kedua jenis ekstrak daun Pelawan Merah tersebut. Mekanisme kerja penghambatan pertumbuhan bakteri oleh Tanin adalah menghambat enzim reverse transkriptase dan DNA topoisomerase sehingga sel bakteri tidak dapat terbentuk (Nuria et al., 2009). Tanin memiliki aktifitas yang berhubungan dengan kemampuannya untuk menginaktifkan enzim dan mengganggu transport protein pada lapisan dalam sel (Cowan, 1994). Menurut Sari dan Sari (2011), Tanin juga mempunyai target pada polipeptida dinding sel sehingga pembentukan dinding sel menjadi kurang sempurna. Hal ini menyebabkan sel bakteri menjadi lisis karena tekanan osmotik maupun fisik sehingga sel bakteri akan mati.

Pada uji aktivitas antibakteri terhadap S.aureus, ketiga jenis ekstrak menunjukkan aktivitas lemah hingga kuat terhadap bakteri S.aureus. Pada konsentrasi 20\% - 60\%, penghambatan pertumbuhan terkategori lemah, pada konsentrasi $80 \%$ - $100 \%$ menunjukkan respon hambat sedang. Konsentrasi $100 \%$ ekstrak etil asetat mampu menunjukkan daya hambat kuat. Pada uji terhadap B.subtilis, ekstrak n-Heksana menunjukkan daya hambat lemah, sementara ekstrak etanol dan etil asetat menunjukkan daya hambat sedang yang terus meningkat hingga konsentrasi 80\%. Pada konsentrasi $80 \%$, ekstrak etil asetat menunjukkan daya hambat kuat terhadap pertumbuhan B.subtilis. Penurunan daya hambat pada konsentrasi $100 \%$ dapat disebabkan kurang sempurnanya difusi ekstrak dan senyawa yang terkandung didalamnya melalui media tumbuh bakteri akibat kekentalan ekstrak.

Kemampuan penghambatan ekstrak erat kaitannya dengan keberadaan senyawa fitokimia yang terkandung. Melihat dari hasil uji fitokimia dan pembuktian aktivitas antibakteri diduga senyawa yang berperan dalam penghambatan pertumbuhan bakteri oleh ekstrak daun Pelawan Merah adalah Flavonoid dan Tanin. Beberapa penelitian menunjukkan aktivitas flavonoid dan tanin sebagai penghambat pertumbuhan bakteri. Berdasarkan hasil uji yang dilakukan, aktivitas antibakteri yang paling tinggi dihasilkan oleh ekstrak etil asetat. Identifikasi fitokimia pada ekstrak etil asetat ditemukan senyawa tanin, sehingga diduga senyawa inilah yang berperan dalam mekanisme penghambatan pertumbuhan bakteri. Berdasarkan hal ini maka perlu dilakukan langkah selanjutnya untuk memisahkan senyawa fitokimia yang aktif berperan sebagai antibakteri dan mengukur kadar senyawa dalam ekstrak guna mengembangkan potensinya sebagai bahan antibiotik.

\section{SIMPULAN}

Berdasarkan uji yang telah dilakukan dapat disimpulkan bahwa ekstrak n-Heksana menunjukkan aktivitas penghambatan lemah terhadap S.aureus dan B.subtilis. Ekstrak etanol menunjukkan aktivitas penghambatan lemah hingga sedang terhadap S.aureus, sedangkan pada E.coli dan B.subtilis tampak adanya aktivitas penghambatan kategori sedang. Ekstrak etil asetat menunjukkan aktivitas penghambatan sedang terhadap E.coli, aktivitas lemah hingga kuat terhadap B.subtilis dan S.aureus.

\section{SARAN}

Perlu penelitian lebih lanjut dengan melakukan isolasi dan pengukuran kadar senyawa aktif untuk memastikan potensi antibakteri daun Pelawan Merah sebelum dilanjutkan sebagai bahan antibiotik alami.

\section{UCAPAN TERIMA KASIH}

Terima kasih kepada Poltekkes Kemenkes Pangkalpinang yang menjadi sumber pendanaan, serta pihak - pihak yang tidak dapat disebut satu per satu yang telah turut membantu pelaksanaan penelitian.

\section{DAFTAR PUSTAKA}

Ainurrohmah, A., E. Ratnasari, L.Lisdiana. 2013. Efektivitas Ekstrak Daun Binahong (Anredera cordifolia) terhadap Penghambatan Pertumbuhan Bakteri Shigella flexneri dengan Metode Sumuran. LenteraBio 2(3): 233 - 237

Asmaliyah, EE. Wati, EA. Waluyo, I. Muslimin. 2016. Kandungan Fitokimia Beberapa Tumbuhan Obat Di Pesisir 
Pantai dan Lahan Basah serta Potensi sebagai Pestisida Nabati. Prosiding Ekspose Hasil Penelitian "Tata Kelola Hutan untuk Mewujudkan Pembangunan Hijau Sumatera Selatan". Palembang, 1 September 2016. Balai Penelitian dan Pengembangan Lingkungan Hidup dan Kehutanan Palembang

Cowan, M.M. 1999. Plant Products as Antimicrobial Agents. Clinical Microbiology Reviews. 12: 564 - 582

Florence, T., D.Gan, M.Hines. 2012. Topical Skin Formulations Comprising Botanical Extract. Paten Amerika (US) 8173184 B2

Ganapathy S, Karpagam S. (2016). In vitro evaluation of antibacterial potential of Andrographis paniculata against resistant bacterial pathogens Methicillin Resistant Staphylococcus aureus (MRSA) and Multiple Drug Resistant Escherichia coli (MDR E. coli). International Journal of Bioassays. 5(3): 4879-4881.

Masyarakat Desa Penagan. 2018. Komunikasi Kelompok Masyarakat Desa Penagan. Dilakukan di Penagan Kecamatan Mendo Barat Kabupaten Bangka 17-18 Februari 2018

Nuria, M.C., A. Faizatun., dan Sumantri. 2009. Uji Antibakteri Ekstrak Etanol Daun Jarak Pagar ( Jatropha cuircas L) terhadap Bakteri Staphylococcus aureus ATCC 25923, Escherichia coli ATCC 25922, dan Salmonella typhi ATCC 1408. Jurnal Ilmu - Ilmu Pertanian. 5: 26 - 37

Palajit, S., A. Varipat, \& V. Asanee. 2008. Evaluation of Antimicrobial from Some Thai wild plants. Proceedings of the 46th Kasetsart

Panagan, A.T dan N.Syarif. 2009. Uji Daya Hambat Asap Cair Hasil Pirolisis Kayu Pelawan (Tristania abavata) terhadap Bakteri Escherichia coli. Jurnal Penelitian Sains.0912-06: 30-32
Sari, F.P., dan S. M. Sari. 2011. Ekstraksi Zat Aktif Antimikroba dari Tanaman Yodium (Jatropha multifida Linn) sebagai Bahan Baku Alternatif Antibiotik Alami. Fakultas Teknik Universitas Diponegoro, Semarang.

Sartika, D. 2013. Uji In Vitro Tanaman Potensial Antiurolithiasis. Skripsi. Fakultas Matematika dan Ilmu Pengetahuan Alam. Universitas Riau. Pekanbaru.

US Patent Application. 2008. Antimicrobial and Pesticidal Composition and Methods Comprising Reduced Monotherpene Oil Extracted from Myrtaceae. Paten Amerika US 20080026083.

Vivi, R. 2017. Isolasi Senyawa Metabolit Sekunder dan Aktivitas Antibakteri dari Ekstrak Kulit Batang Tumbuhan Tristaniopsis merguensis Griff. Skripsi. Universitas Andalas, Padang. 